\title{
体育の授業に対する適応：中学生の場合 \\ 佐々木万丈 \\ Adjustment to physical education classes : a case of junior high school students
}

\author{
Banjou Sasaki
}

\begin{abstract}
A study was conducted to measure the extent of junior high school students' adjustment to physical education classes. Analysis was conducted on 459 male and 297 female junior high school students. First, a scale to measure the extent was developed, which consisted of 14 items and two subcategorized factors: "intention of solidarity," and "adjustment to physical education classes". The reliability was assured by Cronbach's $\alpha$, corrected item-total correlation and the test-retest method, and the criterion-related validity was also supported by comparing the scale score with the physical competance test developed by Okazawa et al. (1996), with satisfying results for both. Next, based on the averages of the created measure's two sub-scales score, male and female junior high school students were classified respectively into the following four types of adjustment to physical education classes: the first type was named "solidarity-adjustment", the second type "peer interaction-maladjustment", the third type "avoiding unity-maladjustment", and the fourth type "at-one's-ownpace-adjustment". The psychological features of these types were considered by comparing their respective stress levels during physical education classes with the psychological stress response test developed by Sasaki (2000). The following results were obtained: 1) Male and female junior high school students who had adapted themselves to physical education classes comprised about $50 \%$ of the whole, respectively. Their lower stress response test scores suggested that they could tackle physical education classes substantiality. 2) On the other hand, there were also comparatively many male and female junior high school students who tended to avoid cooperative activity in their physical education classes. These students comprised about 30\% of the total. Furthermore, their remarkably high stress level suggested that they had lapsed into lack of motivation to physical education classes. We then considered the problem of how physical education classes could be developed to accommodate this group.
\end{abstract}

Key words : factor analysis, self-evaluation scale, average of scale, classification (Japan J. Phys. Educ. Hlth. Sport Sci. 48: 153-167, March, 2003)

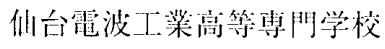

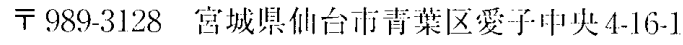

連絡先 傏々水万文
Sendai National College of Technology

4-16-1 Chuou, Ayashi, Aoba-ku, Senndai, Mizagi 989-

3124

Correspondingauthorbsasaki@cc.sendai-ct.ac.jp 
キーワード：因子分析，自己評価尺度，尺度平均， 分類

\section{I 問 題}

電子メディアの発達は積極的な生活変化をもた らす一方で，ストレスの増加や体力の低下，運動 不足などをもたらすと考えられている（宮田， 1993)。したがって，生活習慣として運動やスポ ーツに親しむことの必要性は今後ますます高まる といえよう。そしてこのことは，学校教育，とり わけ体育の授業では，運動やスポーツに対する愛 好的態度の育成が引き続き重要な課題であること を示唆している。

ところで，運動やスポーツに対する愛好的態度 を育てるには，技能や体力などの身体的能力を高 めるだけでは十分とはいえない，連動やスポーツ に積極的にかかわるための心理的能力が高められ ることも必要である。心理的能力とは，意欲や態 度あるいは動機づけなど，これまで様々な視点か ら問題とされてきた心理的諸側面の働きが統合的 に発揮されたときの機能を指す。本研究ではこの ような統合的機能として「適応」に着目し，中学 生の体育の授業に対する適応について考察する。

「適応」とは心理学が扱う最も基本的な問題で ある（宮城，1981）。しかし，その概念的規定は いまだ明確ではない（堂野，1999）。そこで本研 究では，既出の定義（戸川，1956；北村，1956） を援用し，体育の授業に対する適応を次の通り捉 えることにした。すなわち，「主体が体育の授業 を成立させている環境的条件に対して調和的関係 にあり，安定しから自律的・自発的に運動やスポ 一ツの学習に取り組んでいる状態，あるいは，そ のような状態を達成するために学漗の目的や目標 ないしは自らの内的な要請に従って自分自身や環 境的条件を改変したりする過程」である。そして， そのような状態が継続し，かつその過程が有効に 機能できているとき，その主体には「適応力があ る」といえる。したがって，意欲や態度，達成に 问けた動機づけなどの諸機能が統合され一つの心 理的能力として運動やスポーツの実践に活かさ
れ，学習の目的や目標，また個々人の目指す目標 に沿っていきいきと活動できている状態が，体育 の授業に適応できている状態ということになる。

では，体育の授業に対する適応はこれまでどの ように捉えられてきたであろうか。本邦では，運 動やスポーツの実践に係わる適応を取りあげた研 究は散見されるが（桂・中込，1990；青木， 1996 ; 吉村, 1997 ; 青木・松本，1997），体育の 授業に対する適応を概念的に規定し考察した研究 はこれまでのところみられない。たた，関連する と思われる心理的側面については多数の研究がな されており，これらから体育の授業に対する適応 の要因や学習過程のあり方について有用な示唆を 見出すことはできる。例えば，梅野・辻野（1982） や梅野ほか（1997）は体育の学習に対する好意的 な態度の形成には，課題解決的な教材編成やグル ープ学習による仲間と協力しながらの学習，また 学習者（児童）の思考・認識を促進させるような 教師の発問活動を主体とした教授活動，あるいは 肯定的・矯正的フィードバックなどが重要である と指摘している。また，高橋ほか（1997）は，教 阨の積極的な相互作用や肯定的なフィードバッ ク・励ましは，子どもたちの授業に対する態度に 肯定的に作用し，学習意欲の喚起を促すと指摘し た．態度の肯定的変容が適応の結果であると考え れば，これらの指摘は適応の過程に対しても同様 の意味を持つと思われる。また，主体的条件に係 わっては西田・澤 (1993), 佐久本・篠崎 (1979), 新矢ほか（1988），波多野・虾村（1981）などの 体育における意欲や運動嫌い，体育嫌いに関する 硎究があげられる。これらの研究からは，課題と しての連動やスポーツに対する効力感，達成感， あるいは自己笑現の感覚などを持てることが，体 育の授業に刘する適応の重要な主体的条件である ことが示唆される。

本研究では「適応」を心理的諸側面の統合的機 能として捉えることについてはすでに述べた通り である。これは，操作的ではあるが，児童生徒の 身体的能力の対岸に心理的能力を据えた場合，こ れを捉える際に，意欲，態度，動機つけけなどの諸 側面に分割して捉える仕方の他に，統合的に捉え 
る仕方を提出したいという考えに基づいている. 学習者の体育の授業における心理的能力を統合的 に捉えることは，意欲や態度などの要素還元的な 特徵分析とは珙なり，全体的な特性の分析を可能 にするといえるすなわち，意欲や態度などこれ まで検証さされてきた心理的諸側面を統合する視点 を持つことにより，それらの有機的関係性が見出 され，ひいては，学習者個々の心理的能力に忍じ た適切な指導・援助のあり方が, 效果的に検傠で きるようになると若えられる。

本研究は，以上の定義と考察に基づき，体育の 授業に刘する適灾の状態を把握する尺度を構成 し，その尺度をもとに中学生の体育の授業に刘す る適応の状態の実態と特徵を検傠することを目的 とする。

ところで，児童生徒を対象とする学校生活適応 尺度は本邦でも複数提出されているが(高瀬ほか, 1986 ; 内藤ほか，1987），その中でも，二宮ほか （1985）は，中学生や高校生の学校生活に対する 適応を考察するための 26 項目からなる適応検査 を作成している。この尺度の特徵は，学校への適 応を学校生活への適志の高さと仲間との連带志向

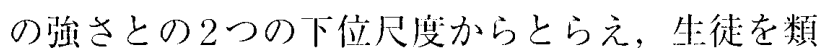
型化できるところにある（恢藤，1996，pp. 573576)。妥当性検䚴:の有無は記述されていないが, 信賴性は高く（ $a=.84$ および.75), また, 類型化 された生徒はその類型特有の心理特性を有してお り，学校への適応状涊が一面的でないことが明ら かにされている（二宮・大野，1990，pp.165174).

一方，体育の学習活動には仲間との様々な相互 作用が含まれており，細江ほか（1990）が指摘す るように，体育は人間関倸の基本である対人構造 が構成される時間として重要と思われる。そして このことは，体育の授業に対して適応することに おいては，共に授業に取り組む仲間との人間関係 にも適応しなければならないことを意味している といえる。したがって，体育の授業に対する適応 の状態を把握するための尺度には，仲間と一緒の 活動に対してどのような志何性を持っているかが 把握できる項目が含まれなけ机ばならないと考え
られた。この点, 二宮・大野の尺度は, 比較的少 ない項目で仲間関係を含む学校生活への適応状態 を把握できる尺度であり，その構成項目は本研究 にも応用できると考えた。そこで本研究では二. 宮・大野の尺度を参考に項目を吟味し尺度を構成 することにした。

\section{II 方法}

\section{1. 被調査者および調查時期}

窝城県内 5 校の中学校生徒 756 名（男子-459 名・文子 297 名, 1 年生 281 名・ 2 年生 197 名・ 3 年生 278 名）が被調查者となり，2000 年 9 月上旬 から11月下訽にかけて調查が策施された。調查 は被調查者の所属する中学校の体育教師が体育の 侍閒内に実施し，その場で回収された。

\section{2. 調査内容}

属性:狱查用紙とともに，以下の 3 つの肘紙を一 度に渡して回答させた。

（1）体育の授業に対する適応の状態を把握す るための調查

二宮・大野の調查䐜目の内，本研究に援用可能 と判断した 22 の刺激文の表現を体育の授業場湎 に合うよう修正し，本調查項目とした。内訳は体 育の授業に対する適応の状態を表す項目が 11 ， 仲間関係に係わる項目が11であった。回答形式 は「まったくあてはまらない」から「大変よくあ てはまる」までの5件法で，分析ではそれぞれに 1 点から 5 点を与えた。

（2）運動有能感調查

岡沢ほか（1996）が作成した運動有能感尺度を 用いた，尺度は 3 つの下位尺度，身体的有能さの 認知, 統制感, 受容感, からなり, 信頼性の高さ が確認されている。なお，回答はオリジナル（岡 沢ほか，1996）では，「どちらともいえない」を 中心に「あてはまらない」2段階，「あてはまる」 2 段階の 5 件法であった。本研究では，有能感の 認知を基本的に「ある」か「ない」かで引き出し， 「ある」場合はより詳細にどの程度かを 3 段階で 捉えられるように，「よくあてはまる」3点，「ま 
あまああてはまる」2点「少しあてはまる」1点, 「あてはまらない」0点の4件法で回答させること にした泪】。

（3）体育の授業における生徒の心理的ストレ 又反応調查

佐々木（2000）が作成した尺度を朋いた。 尺度 は5つの下位尺度,「悲哀・落胆」9項目 $(\alpha=.90)$, 「気力欠如」 6 項目 $(a=.85)$, 「怒り - 不機嫌」4 項日 $(a=.86)$,「恐れ ·心配」4項目 $(a=.78)$, 「落ち着き火如」3 項目 $(\alpha=.76)$, 加構成され ている，回答は 4 件法で，「よくあてはまる」「ま あまああてはまる」「少しあてはまる」「あてはま らない」をそれぞれ3 点から0 点と得点化した。

\section{3. 統計処理}

全てのデー夕処理は，パーソナルコンピュータ 一用統計ソフト「SPSS10.0 J for Windows」を用 いて行った。

\section{III 結果および考察}

\section{1. 分析（1）：尺度の作成および信頼性・妥 当性の検討}

（1）項目の決定

適応の状態を把握する各項目の回答分布を, 平 均值，標準偏差，歪度などから検討した。その結

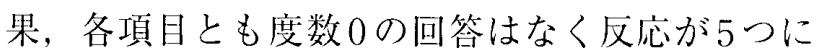
分散しており，回答の極端な偏りはないと判断さ れた。また，各項目評定值の平均 $\pm 1 S D$ を基集 に被調查者を評定值高群と低群とに分け，群間で 項目得点の平均值を比較した $(\mathrm{t}$ 検定 $)$ 。その絬 果, 全項目に㧍いて $5 \%$ 水準の有意差が認められ た。したがって，各項目の識別力は満足できると 判断した。 以上の結果をふまえ, 因子分析は 22 項目すべてに対して行うことにした。

因子分析（主因子法・プロマックス回転）は2 回行った. 1 回目は22項目が対象で, 得られたパ ターン行列をもとに因子を十分に反映古る項目を 選択した。 2 回目は 1 回目の分析で選択された項 目に対して行い，因子の安定性を検証した。2回
とも因子の抽出は初期固有值 1 以上を基準とし, 因子の解釈はパターン行列の因子負荷量が.40以 上の項目内容に基づいた。 なお，因子の解釈では， 複数の因子に.40以上の因子負荷量を持つ項目， また，因子負荷量が.40未満の項目は除外した。

1 回日の分析では 3 因子が抽出された。第 1 因 子（固有值 6.34）は6 項目で「体育の授業に対し て適忍している状態を説明与る因子（以下「体育 適応」)」, 第2因子（固有值 2.20）は8項目で「仲 問に刘する連带志问性を説明する因子（8項目， 以下「連带志向」)」, 第 3 因子（固有值 1.32）は 4 項目（表 1 注 4）で「体育の授業に対する不適応 の状態を説明する因子」と解釈された。因子間相 関は，第 1 因子と第 2 因子が-.51，第 1 因子と第 3 因子が-. 65 ，第 2 因子と第 3 因子が.47であった。 な掞，表 1 の注 5 に示す 4 項目は因子負荷量が.40 未満のため解䣋から除外した。

ところで，抽出された 3 因子の初期固有值は全 て1以上であった。したがって，各因子の持つ情 報の大きさは十分であり，これらを尺度の構成項 目とすることに問題はないと思われた。しかし， 因子間相関をみると，特に第 1 因子と第 3 因子と の間で强い逆相関の関連がみられ，内容的にみて も対称的ではあるが同義と解釈できた。抽出され た因子の構成項目を用い，仮定される心理的側面 の構成概念を把握しようとする場合，解橎のし易 さという点では下位尺度の内容は重複せず，また， 項目数も少ない方が望ましいと考える。そこで, 第 1 因子と第 3 因子についてはいずれか一つを下 位尺度とすることにした。そして，「適応の状態」 を把握するという尺度利用の前提に基づき，第 1 因子の構成項目を下位尺度とすることにした。

以上により 2 因子を構成する 14 項目が選択さ れ，再度，因子分析が行われた，結果は表 10 通 りである。因子の抽出順が1回目とは異なったが， 各因子の項目構成は同じであり，因子負荷量も全 て.40以上であった。すなわち，第 1 因子には 「連荋志向」（初期固有值 4.22），第 2 因子には 「体育適応」（初期固有值 1.92）がそれぞれ抽出さ れた。これにより，選択された 14 項目によって 「連带志向」と「体育適応」の2 因子を説明でき 
表 1 体育の授業に対与る適心の状態を表古項目の因子パ夕ーン行列

\begin{tabular}{|c|c|c|c|c|c|}
\hline 項目 & 因子抽出順 & I & II & 共通性 & $\mathrm{r}$ \\
\hline (4) & 友だちといっしょのグループや班をつくるのはいやだ & $\underline{64}$ & .10 & .42 & .51 \\
\hline (18) & $\begin{array}{l}\text { 友だちといっしょに耿り組むより一人で運動している方が気が } \\
\text { 楽だ }\end{array}$ & $\underline{.63}$ & .05 & .40 & .53 \\
\hline (12) & 友だちといっしょの授袜がうっとうしいと思うことがある & .62 & .02 & .38 & .54 \\
\hline$(22)$ & 友だちから相手にされなくともかまわない & .56 & .21 & .36 & .40 \\
\hline 20 & 体育の時閂はできるだけ友だちと活動するようにしている & -.52 & .08 & .28 & .49 \\
\hline (14) & 体育の授紧では仰の艮い友だちグループがない & .52 & -.05 & .27 & .47 \\
\hline 6 & 北まし合ったり教え合ったりする友だちがいる & -.50 & .17 & .28 & .51 \\
\hline 2 & 友だちといっしょに動き回るのが楽しい & -.50 & .23 & .30 & .52 \\
\hline 5 & 体育の先生に対しては親しみを感じる & .09 & .69 & .48 & .55 \\
\hline 1 & 体育の授業に满足している & -.02 & .66 & .44 & .57 \\
\hline 13 & 体尙の授業を受けていると連動やスポーツのことが理解できる & -.08 & $\underline{.59}$ & .35 & .55 \\
\hline 9 & 体育の授紫は将来の自分の生活に役立つと思う & .09 & .57 & .33 & .46 \\
\hline 17 & $\begin{array}{l}\text { 先生にはわからないことやできないことを筫闣したり相談した } \\
\text { りするとができる }\end{array}$ & .00 & .55. & .30 & .49 \\
\hline 21 & 体育の授業中は約束牙や規則は守る方だ & .03 & .50 & .25 & .41 \\
\hline \multicolumn{2}{|r|}{ 固定值 } & 4.22 & 1.92 & & \\
\hline \multirow{3}{*}{\multicolumn{2}{|c|}{ 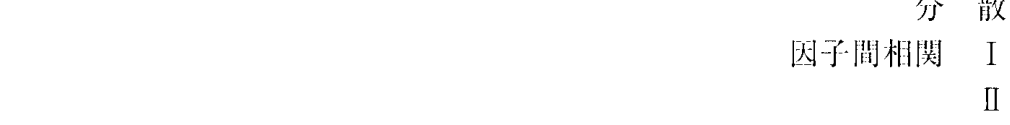 }} & 30.12 & 13.68 & & \\
\hline & & 1.00 & & & \\
\hline & & -.49 & 1.00 & & \\
\hline
\end{tabular}

注 1) 各俱目の番昂は洞查用紙の記載順番

注 2) $\mathrm{r}$ は項目得点と尺度総合得点との闒の相闺係数

注3）番昘が( )で括られた項目は反転項目

注 4）休育の授業に出たくないと思うことがある。私にとって体育の眭䦌はいごこちが琹い，体育の授業は受けてい て苗痛だと思うことがある。体育の授深は特問の無䭾だと思うことがある。

注５）休育の授業が早く終わってしまったと感じることがある．体育の授業では，授業中でも拈もしろくなけ机ば别 のことをしていてもかまわないと照う，友だちとどうしたらじょうずにできるようになるかなどを話すことは ない，体育以外のことを犮だちとよく話す。

ることが示唆された。なおこのときの阔有值寄 与率は $43.8 \%$ ，因子間相関は一.49であった。

ところで，抽出された 2 因子が体育の授業に対 する適応の状態を把握するための因子として構成 概念的に妥当かどうか，あるいは2因于のみで体 育の授業に対する適応の構成概念を十分把握し得 るのかどうかについては異論もあると思われる。 しかし, 本研究ではこの点については既述の通り, 適応という心理的機能を操作的ではあるが統合的 に捉えたいと考え，このことをふまえて尺度構成 の原尺度に二宮・大野の尺度老用いた。したがっ て, 本研究の因子分析結果は, 項目内容を体育の 授業場面に沿うよう修正したものではあるが，二 宮・大野が同定した構成概念を同じように説明し ているといえる。さらに，適応の状態を同定する 第 2 因子をみると，心理的諸側面の積極的な働き
によって導かれた心身の状態で体育の授業に取り 組むことができていることを端的に表している内 容といえる．以上のことから，本研究の定義に基 ついた適応の状態に対しては，抽出された 2 因子 は構成概念的に因子的妥当性と内容的妥当性を有 していると判断した.

以上により，体育の授業に対する適灾の状態を 把握するための尺度項目（以下，適応尺度）には 14 項目を採用し，2因子の構成項目に刘する評定 合成得点を各下位尺度得点とすることにした。な お，以後の分析では，評定值の解釈を容易にする （得点が高いほど適灾の水準が高く，得点が低い ほど適応の水準が低いと解勫する）ため，内容が 不適応状況を表す項目は反転項目として得点化す ることにした。

（2）信頼性 
各下位尺度ごとに求めた項目得点と尺度総合得 点との間の相関係数は表1の通りである。「連带 志向」は.40から. 54 ,「体育適応」は.41 から.57の 值を示し, 中程度以上の強さの相関が認められた。 また，クローンバックの $a$ 係数は「連带志向」 が.79,「体育適応」が.76, 折半法によるスピアマ

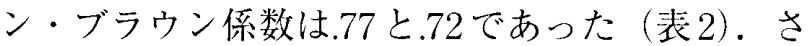
らに，756名の被調查者とは別の男女中学:生 40 名 を対象に 14 項目の調査を 2 回（2001年11月中旬 と 12 月上够）行い，再テスト法の信賴性係数を 求めた (表 2$)$. 調查は 2 回とも同一単元計画の期 間内に実施した。間隔は 2 週間であった。結果は 「連带志河」が.82，「体育適応」が.74であった。 以上により，各下位尺度の内的一貫性と信頼性は 満足できる範囲にあると考えられた。

（3）妥当性

基準関連妥当性を検証するために，運動有能感 尺度と心理的ストレス反応尺度の下位尺度得点と 適店尺度の下位尺度得点との相関係数を求めた。 結果は表3の通りである。

運動有能感尺度と適応尺度とでは全ての下位尺

表 2 信頼性係数

\begin{tabular}{c|c|c|c}
\hline 下位尺度 & I & II & III \\
\hline 連带志何 & .79 & .77 & .82 \\
体育適応 & .76 & .72 & .74 \\
\hline
\end{tabular}

注) $\mathrm{I}=\alpha$ 係数

II =スピアマン・ブラウン係数 III $=$ 再テスト法
度で有意な正の相関係数が得られた。西田・澤 （1993）は運動課題に対して「できそうだ」とい う期待が高いほど授業での学習意欲も高くなると 指摘した。「できそうだ」という期待が高い場合， その根底には相応の高さの「自己の運動能力や運 動技能に対する肯定的な認知」，すなわち「身体 的有能さの認知」があると思われる。このことか らすると，体育の授業に対する意欲の高さを規定 する要因には，身体的有能さに対する肯定的な認 知があげられよう。授業に対する高い意欲は，適 応の過程に対しても肯定的な機能を果たすと思わ れるので，身体的有能さの認知の高さは体育の授 業に対する適応の状態の認知に対しても同様の影 響を与えると考えられる。したがって，「身体的 有能さの認知」と「体育適応」が正の相関を示し たことは妥当な結果と考えられた。また，同様の 関連が「連带志向」との間でもみられた。授業に 意欲的に取り組めるのであれば，環境的条件とし ての仲間との相互交渉に対しても肯定的な認知が 持てるようになると考えられる。したがって， 「連带志向」との正の相関も妥当な結果と考えら れた。

「統制感」は，練習の継続や努力によって自己 の運動能力や技能をどの程度向上できるかという 認知の下位尺度である。「失敗経験の反復」や 「劣等感」は運動嫌いを生み出す主要な要因であ る（波多野・中村，1981）。すなわち，運動能力 や技能の向上を自ら統制できないという認知が繰 り返されたり，そのことで生じる閉塞的な感情が

表 3 適応尺度と運動有能感尺度および心理的ストレス反応尺度の相関

\begin{tabular}{|c|c|c|c|}
\hline \multirow{2}{*}{\multicolumn{2}{|c|}{ 下位尺度 }} & \multicolumn{2}{|c|}{ 適杺尺度 } \\
\hline & & 連帯志向 & 体育適灾 \\
\hline 連動有能感尺度 & $\begin{array}{l}\text { 身体的有能さの認知 } \\
\text { 統制感 } \\
\text { 受容感 }\end{array}$ & $\begin{array}{l}.17^{* * *} \\
.33^{* * *} \\
.57^{* * *}\end{array}$ & $\begin{array}{l}.34 * * * \\
.44 * * * \\
.47^{* * *}\end{array}$ \\
\hline 心理的ストレス反応尺度 & $\begin{array}{l}\text { 悲哀·落胆 } \\
\text { 気力火如 } \\
\text { 怒り·不機嫌 } \\
\text { 恐れ·心配 } \\
\text { 落ち着き火如 }\end{array}$ & $\begin{array}{l}-.18 * * * \\
-.34 * * * \\
-.20 * * * \\
-.32 * * * \\
-.01\end{array}$ & $\begin{array}{l}-.11 * * \\
-.49 * * * \\
-.31 * * * \\
-.20 * * * \\
-.04\end{array}$ \\
\hline
\end{tabular}

$* * \mathrm{p}<.005 \quad * * * \mathrm{p}<.001$ 
固着したときに連動嫌いが生み出されると考えら れる。この場合，運動嫌いを不適応状態と考えれ ば，能力や技能の向上に対する統制感の有無は適 応を規定する中心的な主体的要因になると指摘で きる、したがって，統制感と適応の状態に対する 認知がやや強い正の相関を示したことは妥当な結 果と考えられた。また，統制感が高く維持できて いるのであれば，自信を持って活動に收り組める ので，仲間との連带も高まると思われる。したが って，「連帯志们」との間でも有意な正の相関が みられたことは妥当な結果と考えられた。

「受容感」は運動場面に㧍忛る教阨や仲間との 肯定的な相互作用に対する認知の下位尺尺度であ る。項目内容からみて「連带志向」との間に強い 相関を示したことは妥当な結果といえる。また， 「体育適応」とも比較的強い相関を示したことは， 周囲との肯定的な係わりは，主体の授業に刘する 態度を積極的にさせるとした先行研究（梅野・过 野，1982；梅野ほか，1997；高橋ほか，1997） の指摘を支持して扔り，妥当な結果と考えられた。 次に，心理的ストレス反応と体育の授業に対す る適応との関係をみると, 全ての心理的ストレス 反応と適応尺度との間に負の相関関倸が認められ た。特に，「落ち着き久如」以外の下位尺度では 相関係数は有意であり，心理的ストレスをより強 く認知している生徒ほど，体育の授業に対する適 灾の状態を低く評価し，仲間との相互交涉も消極 的であることが示唆された。なかでも，「気力火 如」と「体育適応」との相関係数が-.49でもっ とも高く，やる気を失うという心理的反応と体育 の授業に対する不適応との関連の深さが示唆され
た。

な掞，「落ち着き欠如」と適応 2 下位尺度との 間で有意な相関が認められなかった原因は，「落 ち着き火如」の項目内容に関連があると思われた。 すなわち，「落ち着き欠如」の項目は，行動に落 ち着きがない，じっとしていられないなどの 3 項 目であった。これらの心理的反応は, 楽しかった りわくわくするような学習場面でも生じることが あると考えられる。したがって，その評定の中に はプラス面での落ち着きのなさも含まれていた可 能性がある。このことが原因となり無相関に近い 値になったと考えられた。

以上, 運動有能感尺度と心理的ストレス反応尺 度とを用いて，適応尺度の基準関連妥当性を検討 した.各下位尺度同士で相関係数を求めたところ， 想定される相互関連を説明できる結果を得ること ができた。したがって，適怘尺度の基準関連妥当 性は満足できる水準にある考えられた。

\section{2. 分析（2）：適応のタイプと特徵}

(1) 適笖尺度得点の男女・学年比較

表4は適応尺度得点の平均（標準偏差）を男女 および各学代ごとに示したものである。二要因分 散分析の結果，「連帯志何」は性 $(\mathrm{F}(1,750)=$ $18.83, \mathrm{p}<.001)$ と学年 $(\mathrm{F}(2,750)=3.23$, $\mathrm{p}<.05)$ の效果がそれぞれ有意であった。学年の 効果はLSD 法による多重比較の結果， 3 年> 1 年 $\doteqdot 2$ 年の大小関係であった $(\mathrm{Mse}=26.87,5 \%$ 水 準).以上のことから，仲間との相互交涉は男子 よりも女子が積極的で，また，学年別にみた場合 は3年生でより顕著なことが示唆された。本結果

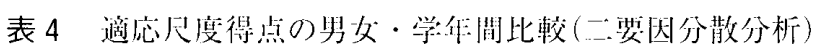

平均 (橴準偏些)

\begin{tabular}{|c|c|c|c|c|c|c|c|c|}
\hline \multirow{2}{*}{$\begin{array}{l}\text { 男子 } \\
\text { 女子 }\end{array}$} & \multirow{2}{*}{$\begin{array}{l}(459 \text { 名 }) \\
(297 \text { 多) }\end{array}$} & \multirow{2}{*}{1 年(281 名) } & \multirow{2}{*}{2 贸 (197 名) } & \multirow{2}{*}{3 年 (278 名) } & \multicolumn{3}{|c|}{$\mathrm{F}$ 值 } & \multirow{2}{*}{ 多重比較 } \\
\hline & & & & & 性 & 学年 & 性×学年 & \\
\hline 速带志润 & $\begin{array}{l}\text { 男子 } \\
\text { 女子 }\end{array}$ & $\begin{array}{l}31.30(5.00) \\
33.08(5.66)\end{array}$ & $\begin{array}{l}31.56(5.28) \\
32.49(5.21)\end{array}$ & $\begin{array}{l}31.89(5.56) \\
34.37(4.31)\end{array}$ & $18.83 * * *$ & $3.23 *$ & 0.31 & $3>1.2$ \\
\hline 体育邀応 & $\begin{array}{l}\text { 男子 } \\
\text { 女子 }\end{array}$ & $\begin{array}{l}20.18(4.58) \\
18.83(4.11)\end{array}$ & $\begin{array}{l}20.44(4.16) \\
19.94(3.93)\end{array}$ & $\begin{array}{l}20.24(5.25) \\
22.36(3.94)\end{array}$ & 0.07 & $11.26^{* * *}$ & $10.96 * * *$ & (表 5 参照) \\
\hline
\end{tabular}

$* \mathrm{p}<.05, \quad * * * \mathrm{p}<.001$ 
は，青年期における自己概念の性差として，特に 女子の自己評価では対人的社会的要因が大きなウ エイトを占めるようになる（柏木，1983）という 指摘に一致しており，一般的な性差が反映された 結果と考えられた。

次に「体育適応」は交互作用が有意であった $(\mathrm{F}(2,750)=10.96, \mathrm{p}<.001)$. 各水準の単純効 果（表5）は，学年別にみた性差が 1 年と 3 年で 有意であり，かつ 1 年と 3 年では男女の大小関係 が逆転した。 2 年は有意とはいえなかった。また， 男女別の学年差では女子が学年間で有意に異なっ て抢り，LSD 法による多重比較の結果， 3 年>2 年 $\fallingdotseq 1$ 年 $(\mathrm{Mse}=19.70,5 \%$ 水準）の大小関係で あった。以上により，「体育適応」の交互作用は, 男子の適応状態に対する認知が学年横断的には差 がみられないのに対し，女子では特に3学年にお いて適応の認知が高まり，さらにその認知レベル が男子よりも高かったことで生じたことが明らか になった。

以上まとめると，体育の授業に対する適応の認 知は，男子では大きな変化はみられず中学 3 华間 を通してほぼ安定した水準で推移すると示唆され た。一方，女子は学年が進むにつれ，仲間との連 带が深まり対人的な相互影響性が高まることで， 体育の授業に対する適応の想知レベルが向_上して いくと考えられた。すなわち，体育の授業に対す る適応の状態は, 中学生では女子が顕著な変動を 示し易いと指摘できるようである。しかし，これ
は本研究の横断的な分析からの見解である。一般 的な傾向であるかどうかは，今後の縦断的な分析 によって検討されなければならないといえる。

（2）適応状態の類型化

適応尺度得点の男女・学年別比較から, 認知別 の類型化は男女別に行うのが適切と判断した。類 型化は「連带志向」と「体育適応」の各平均值で それぞれを上下 2 群，全体で 4 群に類型化した (図 1).

第 1 像限は各下位尺度得点がいずれも平均值以 上の生徒群である。すなわち, 連带志向が強く仲 間といっしょに積極的に授業に取り組み，体育授 業の意義をよく理解して運動やスポーツでの自己 実現に向け前向きに取り組むことができている生 徒群といえる。そこで，この生徒群の適応の夕イ プを「連带一適応型」（以下，「連带型」）と呼ぶ ことにした。次に，第2象限は「連带志向」は平 均值以上であるが「体育適応」は平均值未満の生 徒群である。すなわち，この生徒群は仲間との協 調的な行動には積極的であるが，学漗としての運 動実践や教師との相互的関係の構築や活動には消 極的で授業そのものには適応できていない生徒群 といえる。そこでこのタイプを「仲間遊び一不適 応型」（以下，「遊び型」）と呼ぶことにした。次 に，第 3 象限は汕下位尺度とも平均值未満の生徒 群である。この生徒群は仲間とは没交渉的で，同 時に，運動やスポーツの実践にも消極的な生徒群 といえる。そこでこのタイプを「脱連带一不適応

表 5 「体育適灾」の父互作用の分析結果

\begin{tabular}{|c|c|c|c|c|}
\hline 塿因 & 平方利 & 自由度 & 平均平方 & F 值 \\
\hline $\begin{array}{l}\text { 性 } \\
1 \text { 年 } \\
2 \text { 年 } \\
3 \text { 年 }\end{array}$ & $\begin{array}{r}1.44 \\
103.36 \\
14.18 \\
254.88\end{array}$ & $\begin{array}{l}1 \\
1 \\
1 \\
1\end{array}$ & $\begin{array}{r}1.44 \\
103.36 \\
14.18 \\
254.88 \\
\end{array}$ & $\begin{array}{c}0.07 \\
5.25 * \\
0.72 \\
12.94 * * *\end{array}$ \\
\hline $\begin{array}{c}\text { 学年 } \\
\text { 男子 } \\
\text { 文子 } \\
\text { 性: ×学牮 } \\
\text { 誤差 }\end{array}$ & $\begin{array}{r}443.41 \\
4.21 \\
739.11 \\
431.63 \\
14771.05\end{array}$ & $\begin{array}{r}2 \\
2 \\
2 \\
2 \\
750\end{array}$ & $\begin{array}{r}221.70 \\
2.10 \\
369.56 \\
215.81 \\
19.70\end{array}$ & $\begin{array}{l}11.26 * * * \\
0.11 \\
18.76^{* * * *} \\
10.96 * * *\end{array}$ \\
\hline 全体 & 15544.37 & 755 & & \\
\hline
\end{tabular}




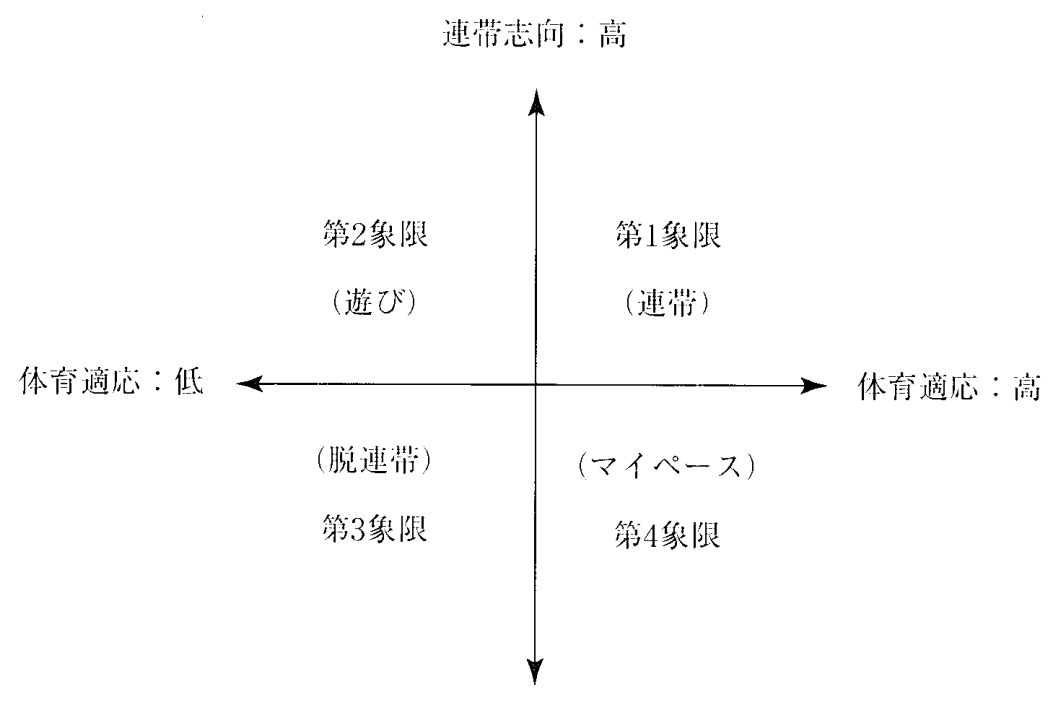

速站琶问：低

図 1 体育の授柴に刘与る適岕の類型

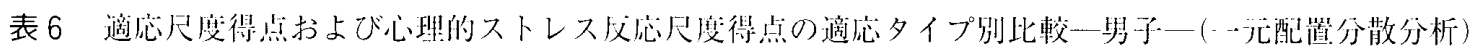

\begin{tabular}{|c|c|c|c|c|c|c|c|}
\hline & \multicolumn{4}{|c|}{ 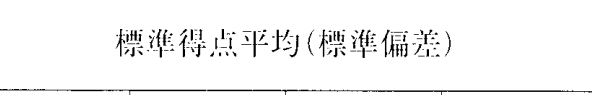 } & \multirow{2}{*}{$\mathrm{F}$ 值 $\cdot \mathrm{df}$} & \multicolumn{2}{|c|}{$\begin{array}{c}\text { 多重比較 } \\
(\mathrm{LSD} \text { 法: } 5 \% \text { 水準) }\end{array}$} \\
\hline & 速谓 & 遊び & 脱連倠 & マイペース & & Mse & 比較 \\
\hline 速带志何 & $\begin{array}{r}0.59 \\
(0.52)\end{array}$ & $\begin{array}{r}0.43 \\
(0.46)\end{array}$ & $\begin{array}{l}-1.09 \\
(0.71)\end{array}$ & $\begin{array}{l}-1.06 \\
(0.75)\end{array}$ & $\mathrm{F}(3,455)=269.65 * * *$ & 0.36 & $1>2>4.3$ \\
\hline 休青適応 & $\begin{array}{r}0.84 \\
(0.61) \\
\end{array}$ & $\begin{array}{l}-0.72 \\
(0.56)\end{array}$ & $\begin{array}{l}-0.94 \\
(0.74)\end{array}$ & $\begin{array}{r}0.52 \\
(0.43)\end{array}$ & $\mathrm{F}(3.455)=247.03 * * *$ & 0.41 & $1>4>2>3$ \\
\hline 悲哀・落师 & $\begin{array}{l}-0.23 \\
(0.89)\end{array}$ & $\begin{array}{l}-0.12 \\
(0.91)\end{array}$ & $\begin{array}{r}0.03 \\
(1.02)\end{array}$ & $\begin{array}{l}-0.05 \\
(0.92)\end{array}$ & $F(3.455)=1.98$ & & n.s \\
\hline 武力久如 & $\begin{array}{l}-0.47 \\
(0.63)\end{array}$ & $\begin{array}{r}0.03 \\
(0.98)\end{array}$ & $\begin{array}{r}0.48 \\
(1.23)\end{array}$ & $\begin{array}{l}-0.30 \\
(0.70)\end{array}$ & $F(3.455)=28.43^{* * *}$ & 0.84 & $\begin{array}{l}3>1.4 .2 \\
2>1.4\end{array}$ \\
\hline 怒り・不機娧 & $\begin{array}{l}-0.26 \\
(0.89)\end{array}$ & $\begin{array}{r}0.03 \\
(1.07)\end{array}$ & $\begin{array}{r}0.21 \\
(1.10)\end{array}$ & $\begin{array}{l}-0.22 \\
(0.85)\end{array}$ & $\mathrm{F}(3,455)=6.48^{* * *}$ & 0.97 & $\begin{array}{l}3>1.4 \\
2>1\end{array}$ \\
\hline 恐れ ·心配 & $\begin{array}{l}-0.28 \\
(0.84)\end{array}$ & $\begin{array}{l}-0.24 \\
(0.80)\end{array}$ & $\begin{array}{r}0.17 \\
(1.16)\end{array}$ & $\begin{array}{l}-0.07 \\
(0.84)\end{array}$ & $\mathrm{F}(3.455)=6.57 * * *$ & 0.88 & $3>1.2$ \\
\hline 落ち着き欠如 & $\begin{array}{l}-0.07 \\
(0.98)\end{array}$ & $\begin{array}{r}0.07 \\
(1.12)\end{array}$ & $\begin{array}{l}-0.04 \\
(0.94)\end{array}$ & $\begin{array}{r}0.14 \\
(0.96)\end{array}$ & $F(3,455)=0.93$ & & n.s \\
\hline
\end{tabular}

$* * * \mathrm{p}<.001$

型」（以下，「脱連带型」）と呼ぶことにした。最 後に，第 4 象限は「連带志问」は平均值未満であ るが，「体育適応」は平均值以上の生徒群である。 すなわち，この生徒群は仲間との協调的活動には 消極的だが，連動やスポーツの実践あるいは教師 との相互的関係の構築や活動には前问きで，自分 の考えに基づいき積極的に授業に取り組んでいる 生徒群とみることができる。そこでこの適応夕イ プを「マイペース一適応型」（以下，「マイペース 型」）と呼ぶことにした。
次に，男女別に各適応タイプの下位尺度得点 （Z得点）を比較し，各タイプの適応の特徵が尺 度得点に反映されているかどうかを検傠した。各 タイプの下位尺度得点の平均值と標準偏差および 一元配蟴分散分析の結果は，男子が表 6 と四 2 , 文子が表 7 と図 3 の通りである（下位検定結果は 表を参照)。

男女とも「連崮志向」「体育適応」のいずれに おいても条件の効果が有意であったＬSD法に よる多重比較の結果，男子では「脱連带型」と 


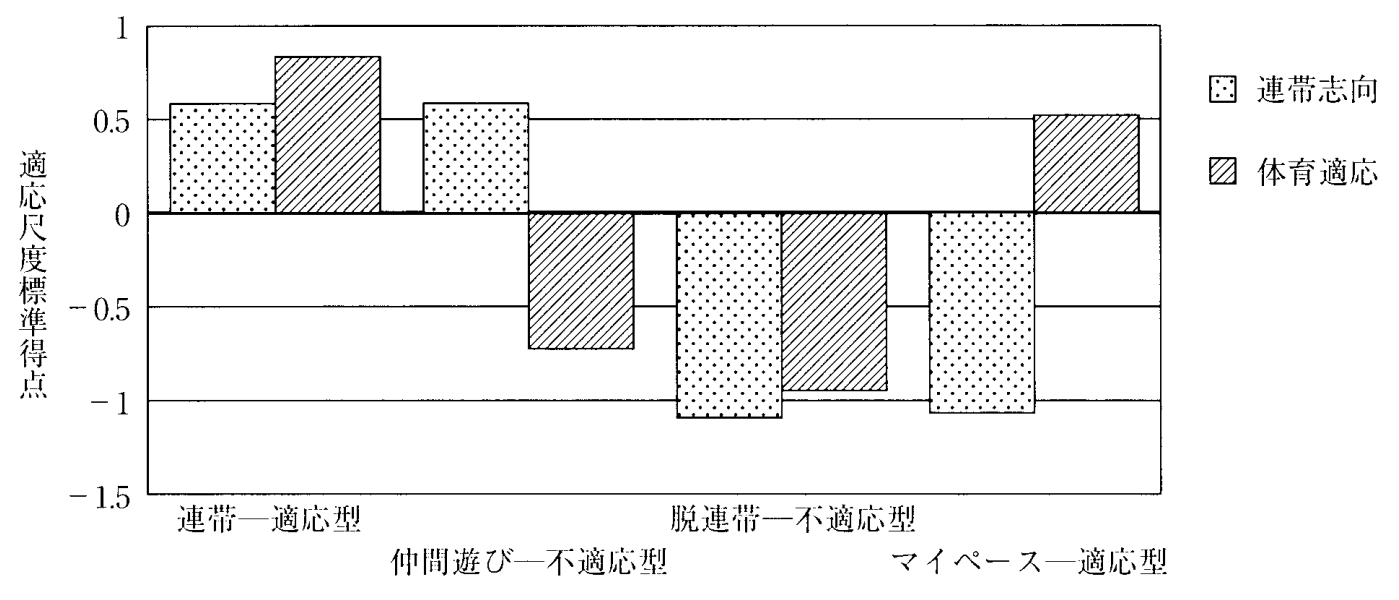

男子適応タイプ

図2 適応尺度得点のタイプ别比較：罗子

表 7 適心尺度得点拉よび心理的ストレス反心尺度得点の適心夕イプ别比較一女子-(一元配㯰分散分析)

\begin{tabular}{|c|c|c|c|c|c|c|c|}
\hline & \multicolumn{4}{|c|}{ 標準得点平均(標準偏差) } & \multirow{2}{*}{$\mathrm{F}$ 做 $\cdot \mathrm{df}$} & \multicolumn{2}{|c|}{$\begin{array}{c}\text { 多重比較 } \\
(\mathrm{LSD} \text { 法· } 5 \% \text { 水準) }\end{array}$} \\
\hline & 連带 & 遊び & 脱逨茜: & マイペース & & Mse & 比較 \\
\hline 連带志问 & $\begin{array}{r}0.92 \\
(0.37)\end{array}$ & $\begin{array}{r}0.88 \\
(0.35)\end{array}$ & $\begin{array}{l}-0.68 \\
(0.94)\end{array}$ & $\begin{array}{l}-0.44 \\
(0.48)\end{array}$ & $\mathrm{F}(3,293)=150.87 * * *$ & 0.37 & 1. $\begin{aligned} 2 & >4,3 \\
& 4>3\end{aligned}$ \\
\hline 体青適応 & $\begin{array}{r}0.80 \\
(0.55) \\
\end{array}$ & $\begin{array}{l}-0.71 \\
(0.59)\end{array}$ & $\begin{array}{l}-0.74 \\
(0.51)\end{array}$ & $\begin{array}{r}0.82 \\
(0.61) \\
\end{array}$ & $\mathrm{F}(3,293)=184.79 * * *$ & 0.31 & $4,1>3,2$ \\
\hline 悲哀·落胆 & $\begin{array}{r}0.02 \\
(0.95)\end{array}$ & $\begin{array}{l}-0.05 \\
(0.98)\end{array}$ & $\begin{array}{r}0.50 \\
(1.17)\end{array}$ & $\begin{array}{r}0.18 \\
(1.08)\end{array}$ & $\mathrm{F}(3.293)=4.49^{* *}$ & 1.10 & $3>2,1$ \\
\hline 気力火如 & $\begin{array}{l}-0.35 \\
(0.72)\end{array}$ & $\begin{array}{r}0.22 \\
(0.98)\end{array}$ & $\begin{array}{r}0.76 \\
(1.04)\end{array}$ & $\begin{array}{l}-0.19 \\
(0.81)\end{array}$ & $\mathrm{F}(3.293)=26.23 * * *$ & 0.79 & $\begin{array}{l}3>1,4,2 \\
2>1,4\end{array}$ \\
\hline 怒り・不機嫌 & $\begin{array}{l}-0.16 \\
(0.87)\end{array}$ & $\begin{array}{r}0.15 \\
(1.01)\end{array}$ & $\begin{array}{r}0.51 \\
(1.12)\end{array}$ & $\begin{array}{l}-0.18 \\
(0.62)\end{array}$ & $\mathrm{F}(3,293)=9.17 * * *$ & 0.90 & $\begin{array}{l}3>4,1,2 \\
2>1\end{array}$ \\
\hline 恐れ·心配 & $\begin{array}{l}-0.26 \\
(0.69)\end{array}$ & $\begin{array}{r}0.11 \\
(0.99)\end{array}$ & $\begin{array}{r}0.61 \\
(1.16)\end{array}$ & $\begin{array}{r}0.39 \\
(1.16)\end{array}$ & $\mathrm{F}(3,293)=12.86 * * *$ & 0.98 & $\begin{array}{l}3>1,2 \\
4>1 \\
2>1\end{array}$ \\
\hline 落ち着き欠如 & $\begin{array}{l}-0.07 \\
(1.00)\end{array}$ & $\begin{array}{l}-0.01 \\
(1.03)\end{array}$ & $\begin{array}{r}0.04 \\
(1.09)\end{array}$ & $\begin{array}{l}-0.10 \\
(0.82)\end{array}$ & $F(3,293)=1.06$ & & n.s \\
\hline
\end{tabular}

$* * \mathrm{p}<.01 * * * \mathrm{p}<.001$

「マイペース型」，女子では「連带型」と「遊び型」 との間で「連帯志向」得点の有意差が認められず, また，女子の「脱連带型」と「遊び型」抢よび 「連帯型」と「マイペース型」との間では「体育 適応」得点の有意差が認められなかった。しかし， それ以外は男女ともに各尺度の有意差が認められ た.

以上の結果, 男子の場合,「脱連带型」と「マ イペース型」の連带志向が同様に弱いことが示唆 されたが，「体育適応」の得点は両夕イプ間で有 意に異なっており，それぞれの特徽を解釈する上
では混乱はないと思われた。したがって，これら 2つのタイプも含め男子各タイプの尺度得点はそ れぞれの適応状態の特徵を反映できていると判断 した。

一方，女子では，男子に比べ尺度得点が複数の タイプでほぼ同じ水準になる場合が多くみられ た。しかし，2下位尺度とも同じ水準にあると思 われる適応タイプはみられず，いずれかの尺度得 点は他の適応タイプと有意に異なっていた。した がって, 男子同様, 解釈上の混乱はないとみなす ことができ，尺度得点にはそれぞれの適応状態の 


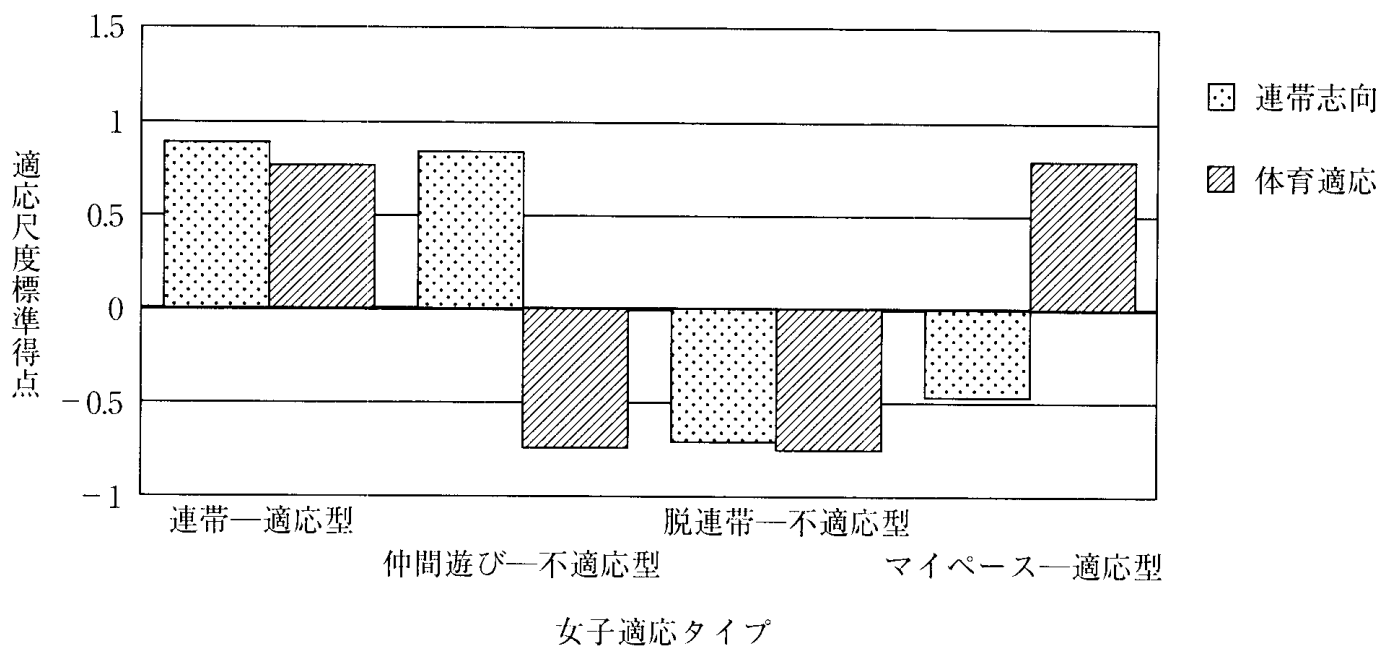

図3 適応尺度得点のタイプ別比校：女子

表 8 適心タイプの坐徒数比較 ( $x^{2}$ 検定)

\begin{tabular}{c|c|c|c|c|c|c}
\hline & 連州 & 遊び & 脱連带 & マイペース & 期待度数 & $\chi^{2}$ 值 \\
\hline 男子 (459) & 174 & 93 & 131 & 61 & 114.8 & $62.19 * * *$ \\
女子 (297) & 99 & 63 & 86 & 49 & 74.3 & $20.40 * * *$ \\
\hline
\end{tabular}

$* * * \mathrm{p}<.001$

特徵が反映されていると判断できた、以上により， 男女とも，適応尺度の平均值に基づく4象限への 類型化では，各適灾夕イプの適応状態の特徵が反 映できていると考えられた。

次に，男女別に，それぞれの夕イプに同定され た生徒の数を比較した（ $\chi^{2}$ 検定）。結果は表 8 の 通りであった，男女ともに各夕イプに同定された 生徒の数は偏っており，その差は有意であった。 各タイプに同数の生徒が分類されると仮定した場 合，期待度数は男子が $114.8 ＼mathrm{~ ， 女 子 か ゙ ~} 74.3$ である。 観測度数とのズレから判断すると，各夕イプの生 徒数の偏りは男女ともに同じ傾问であることが示 唆された。なかでも最も多くの生徒が同定された タイプは「連带型」(男子：38\%，女子：33\%) であった。また，「連带志向」は強くないが授業 そのものには適応できていると考えられる「マイ ペース型」(男子：13.3\%，女子：16.5\%) と 「連带型」とを合わせると，体育の授業に適応で きていると思われる生徒は男女ともに全体の半数 を超えていた（男子：51.3\%，女子：54\%)。一 方，適応の状態としては最も深刻と思われる「脱
連带型」への同定数も比較的に多く（男子： $28.5 \%$, 女子： $30 \%)$, その数は「連带型」に次 ぐものであった。「問題」においてすでに指摘の 通り，今後の生活スタイルの変化を考えた時，運 動やスポーツに自発的・自律的に親しむことので きる個人の育成は重要と考えられる。このことを 考虑すれば不適応夕イプの生徒を減らし，適応夕 イプの生徒をより多くしていくことは今後も体育 授業の課題として重要と考えられた。

また，「遊び型」には男女でほぼ同じ割合の生 徒が同定された（男子：20.3\%，女子：21.2\%)。 期待度数との比較からすれば，その数は多いとは いえない。しかし，学習集団の中でこれらの生徒 が他夕イプの生徒に対して与えるかもしれない影 響を考えた場合，その数が全体の 2 割に及ぶこと には注意を払う必要があると考える。それは，積 極的に学習に取り組もうとしている者にとって 「他者の不真面目」はやる気を阻害する要因にな るとの指摘（佐々末，1996）があり，「遊び型」 生徒は授業に集中せず仲間とたむ万することで, 他者の学習活動への集中を阻害することが危惧さ 
れるからである，体育の授業に対する学贸集団全 体の集中力や積極さが損なわれることは，学習目 標の達成のため，また，活動中の安全のためにも 避けられなければならない。

（3）各適応夕イプの心理的特徵

男女別に各適応タイプの心理的特徵を把握する 目的で，それぞれの適応夕イプの心理的ストレス 反応尺度得点を比較した（一元配置分散分析）. 分析結果は男子が表 6 と図 4, 女子が表 7 と図 5 の通りである(下位検定結果は表を参照)。

男子は，「悲哀・落胆」と「落ち着き欠如」を 除く 3 下位尺度で条件の効果が有意であった。 LSD 法による多重比較の絬果，「気力火如」は 「脱連帯型」の認知得点がもっとも高く，次いで
「遊び型」が高かった。一方もっとも低かったの は「速带型」で，次いで「マイペース型」が低か った，以下，「怒り・不機嫌」の諗知高群は「脱 連带型」と「遊び型」，低群は「連带型」と「マ イペース型」「恐れ・心配」の認知高群は「脱連 兴型」，低群は「連枣型」と「遊び型」であるこ とが示唆された。

女子は，「落ち着き火如」を除く 4 下位尺度で 条件の效果が有意であったＬSD法による多重 比較の結果，「悲㚃・落胆」の認知がもっとも高 かったのは「脱連带型」，もっとも低かったのは 「遊び型」であった。連带型」は「遊び型」に次 いで低かった。「気力欠如」は男子と同様「脱連 鱼型」の認知得点がもっとも高く，次いで「遊び

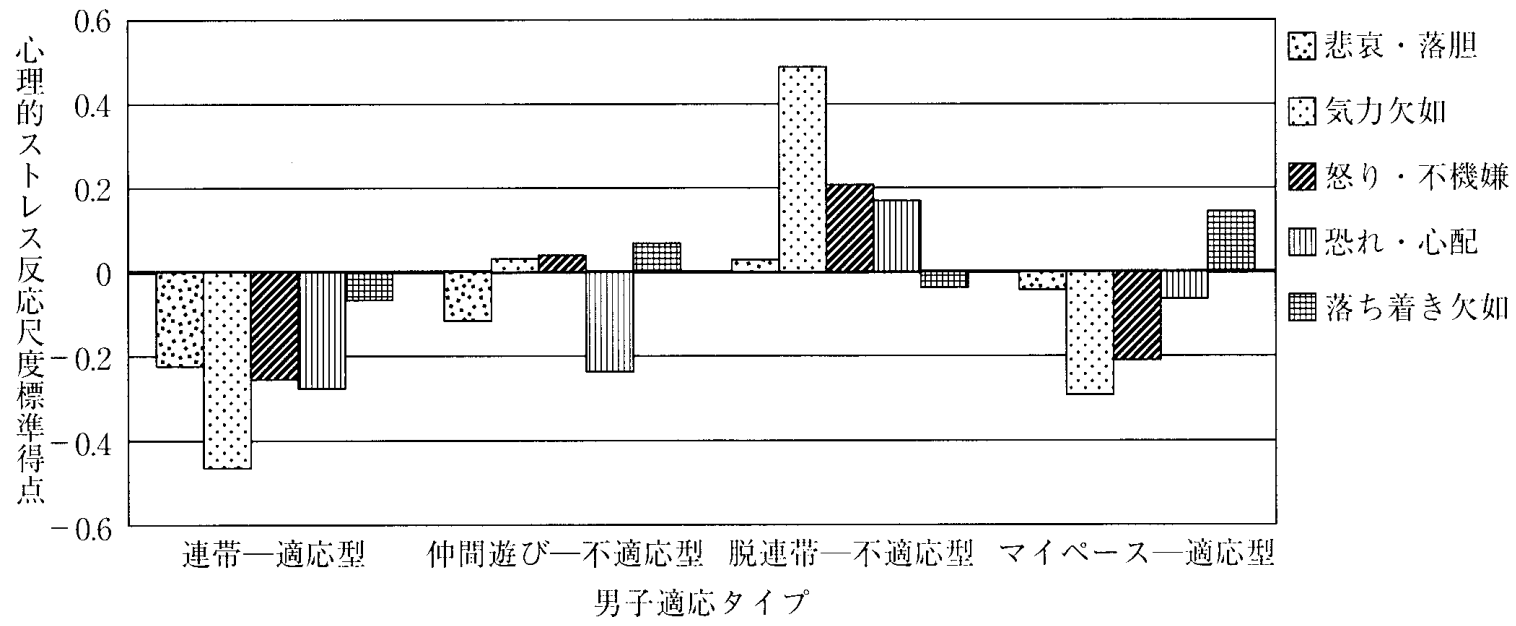

図4 心理的ストレス反応风度得点の夕イプ別比較：男子

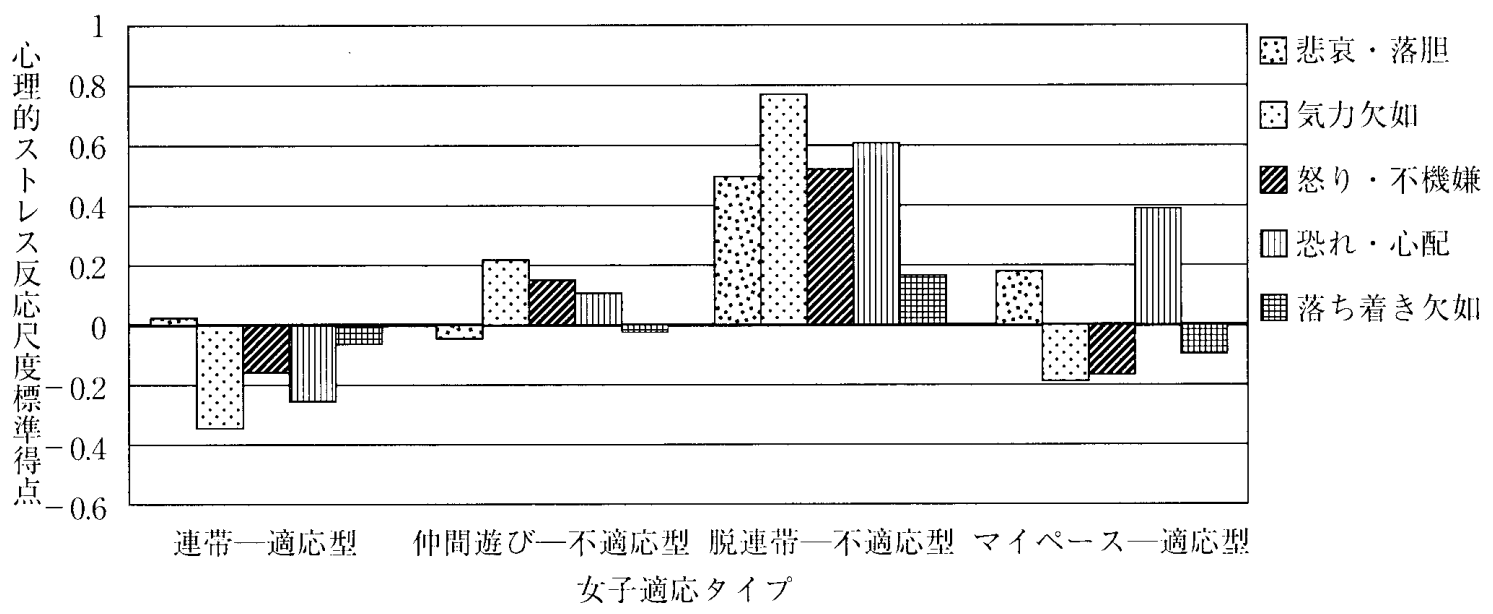

図5心理的ストレス反矿尺度得点のタイプ㓢比較：女子 
型」が高かったももっとも低かったのは「連带型」 で，次いで「マイペース型」が低かった。以下， 「怒り・不機嫌」の認知高群は「脱連带型」, 低群 は「マイペース型」と「連倠型」，「恐れ・心配」

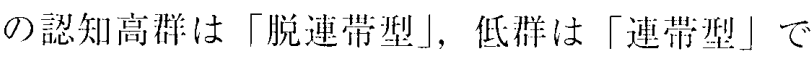
あることが示唆された。

以上をまとめると，体育の授業において心理的 ストレス反応を強く認知しているのは劦女ともに 「脱連带型」であるといえる。特に「気力欠如」 の認知は他群と比べても際だって高い。また，特 に女子の「脱逨带型」では，「悲哀・落胆」，「怒 ク・不機嫌」，「恐れ・心配」についても高いこと が示唆された。これらから，女子の「脱連帯型」 の不適応状況は心理的にみてきわめて哚刻な状況 にあると指摘できるようである。自己詽洒におい て対人的要因が重視されるという女子の特徎を考 慮した場合，対人的構造の構築が文子の体育授業 に対する適応感を高めることに大きな影響力を持 つことを，これらの結果は示唆している。教師は 「脱連带型」に同定されるような生徒に刘しては, いかなる理由から周罒と没交渉になったのかを探 り，必装に応じて適切な介入を行うことが重要と いえよう。

次に，仲間との人間関係に対する適応が重要と 考える本研究の立場とは逆に，連带志何が低いに もかかわらず体育の授業に適応できていると考え られた「マイペース型」は，男女ともに心理的ス トレス反忍の少ないことが示唆された。これによ り，「マイペース型」は体育の授業に適応できて いる生徒群とみなすことができると考えられた。 また，このことをふまえると，体育の授業に対す る適応を促すために仲間との積極的な相互交涉を 一義的に求めることはできないとも考穴られた。 すなわち，仲間と積極的に相互交涉ができるよう な体育の授業であることは，刘人的構造の構築が 重要であるとする立場からは基本としながらも， それをいかに活用するかでは，個々の生徒の心理 的要求に従う柔軟な展開を考えなけ扎ばならない といえるようである。

次に，「遊び型」は，「脱連帯型」ほどではない が，「連带型」や「マイペース型」と比較した場
合，心理的ストレス反忍の水準が高いと考えられ た。なかでも「気力欠如」が男文ともにやや高い ことからは，「遊び型」生徒の，授業に対するや る気のなさが示唆され，仲間とは楽しくしていた いだけという消極的な心理傾问が浮き溒りになっ た.またこのような心理的状沉を考えた場合， 「遊び型」の「連带志们」の高さを，本研究の前 提である体育授業への適応を促す仲閏関係への適 忘の高さと捉えることはできないといえる。教仰 が生徒同士の相互的関係に指導的な介入を行う埸 合には，その生徒の「連耑志向」が動機的にどの ような意味を持つのかを解彩する必要があるとい えよう。

しかし一方で，女子の「遊び型」は「悲哀・落 胆」の反応得点がもっとも低く，また，「恐れ。 心配」の低い傾向は男父雨方に認められた。この ことは，体育の授業に適応できているかどうかに はかかわらず，仲間との交渉が積極的である場合 には，授業中に生じるネガティブな感情が緩衝さ れ易いことを示唆していると考えられた。

最後に，「速带型」は男女ともに心理的ストレ ス反応の水準が低かった。このことは，「逨帯型」 生徒の心理的安定性の高さを示しているといえ る、なかでも，「気力欠如」の水準は他群と比較 しても顕著に低く，「逨㨽型」生徒の「やる気」 の高さを示す結果として注目された。

以上，作成された尺度をもとに生徒を類型化し その特徵を考察してきたが，今後は次の点につい て検討されなければならないと考えられた。

一つには，適応の過程についての考察である。 本研究では心理的諸側面の統合的機能である適応 の過程から導かれた「適応の状態」を操作的に仮 定し，その把握を行うと共に他の心理的要因との 関連を考察した。今後は，すでに種々の検傠が行 われている体育の学習に対する意欲や態度などの 心理的諸倒面が，いかに機能的に統合され適応の 状態が導かれるのか, その関係性を構造的に把握 し「適応の過程」を検討しなければならないとい える。

二:つには，その適応の過程をモデルとして提出 し, 本研究で明らかになった不適応状態の生徒を 
いかに適応の状態に導くかを実践的もしくは臨床 的に検討していくことである。これにより，意欲 や態度など心理的諸側面の授業場面での機能が有 機的に明らかにされ，運動やスポーツに積極的に 係わることができる主体育成のための授業プログ ラムが，適応という視点に立って提出できるよう になると考えられる。

\section{III まとめ}

本研究の目的は，中学生の体育の授業に対する 適忍の状態を考察することであった。まず，適応 の状態を把握するための尺度が構成され信頼性と 妥当性が検討された。検討の結果はほぼ満足でき るものであった，次に，構成された尺度を用いて 中学生の体育の授業に対する適応の状態を把握 し，下位尺度の平均值に基づいて生徒を類型化し， それぞれの夕イプの心理的特徵を考察した。そのの 結果，男女ともに人数の偏りはあるものの，想定 した4つの適応の状態に生徒を類型化でき，体育 の授業に対する適灾の状態は多様に捉えられ，ま た，その心理的特徵はそれぞれで異なることが示 唆された。

最後に，これらの結果をもとに，この分野での 今後の研究方向について考察を行った。

\section{注}

注1）岡沢ほか（1996）と同様の手続きによる因子分 析（因子数を固有值 1.00 以上で嫢定した主成分 分析・バリマックス回転）を行った結果，抽出 順は異なるが，盛沢ほか（1996）と同じ項目構 成の 3 因子が抽出された。各因子の構成項目（番 号）と因子負荷量は以下の通りであった。第 1 因 子 $\lceil 4-84,11-.84,3-.82,12-.82\rfloor$, 第 2 园 子 「1-.87, $10-.83,2-.82,8-.77\rfloor$, 第 3 因 子「 $77-.84,6-.80,9-.77,5-.56\rfloor$.これに より，4作法による回答形式でも問題はないと判 断した.

\section{文献}

青木邦男（1996） スポーツ少年団への団員の過度適 応と学校への適応との関係. 体育学研究 $40 ： 291$
$-303$.

青木邦男・松本耕二（1997）高校運動部員の部活動 適応感に関連する心理社会的要因. 体育学研究 $42: 215-232$.

堂野佐俊（1999）現代社会におけるストレスと適応 の生涯発達心理学. 風間書房 : 東京, pp. 90-91. 波多野義郎・中村精男（1981）「運動ぎい」の生成

機序に関する事例研究。体育学研究 $26 ： 177-$ 187.

細江文利 - 青木 真 · 品田龍吉 - 池田延行 (1990) こども・せんせい・がっこう。大修館書店：東京， pp. $69-72$.

桂 和仁・中迟吅郎（1990）運動部活動に扮ける適 灾感老規定する装因. 体育学研究 35：173-185. 柏木惠子（1983）子どもの「自己」の発達. 東京大 学出版会：東京, p. 92 .

北村晴朗（1965）適灾の心理. 誠信書房：東京, p. 11.

久笹敏雄・二宮克美 $\cdot$ 大野 久（1985）中学生・高 校生の学校生活への適応に関する一研究. 日本教 青心理学会第 27 回総会発表論文集：404-405.

宮城音弥（1981）新 - 心理学入門。岩波書店：束京, pp. $1-2$.

宮田加久子（1993）電子メディア社会 新しいコミ エニケーション環境の社会心理. 誠信書房：東京, pp. $82-121$.

内藤勇次 - 浅川潔司 - 高瀬克義 - 古川雅文 - 小泉令 三（1987）高校生用学校環境適応感尺度作成の試 み。兵庫教育大学研究紀要 $7(1)$ ：135-146.

二容克美.大野 久（1990）学校生活に扮ける青年. 久世敏雄編 変貌する社会と青年の心理. 福村出 版：東京, pp. 157-182.

西田保・澤 淳一（1993）体育に扔ける学習意欲 を規定する要因の分析．教育心理学研究 $41 ： 125$ -134 .

岡沢裶訓・北真佐美・諏訪鿆一郎（1996）運動有能 感の構造とその発達及び性差に関する研究. スポ 一ツ教育学研究 $16 ： 145-155$.

佐久本稔・篠崎俊子（1979）学校体育期の“運動嫌 い”に関する研究 (I). 福岡女子大学家政学部生 活科学 12(1)：55-78.

佐々木万丈（1996）中学校体育の授業における生徒 の心理的ストレスと学習条件一無力的認知・思考 を生起させるストレス因の分析を通して一。東北 
体育学研究 $14: 61-73$.

佐々木万丈（2000）中学生用体育学習心理的ストレ ス反応尺度の開発および対人関係に対する主観的 評価と心理的ストレス反応との関係. 日本体育学 会第 51 回大会号：173.

佐藤有耕（1996）適応と問題行動. 堀 洋道 - 山本 真理子・松井 豊編 心理尺度ファイル人間と 社会を測る。垣内出版：東京, pp. 570-597.

新矢博美 - 松田憲明 - 中嶋輝雄 - 田中喜代次 -中塘 二三生（1988）運動の好き嫌いと体力・運動能力 との関係．教育医学 34：132-135.

高橋建夫 - 林 恒明 - 鈴木和弘 - 日野克博 - 深見英

一一郎・平野隆治 (1997) 体育授榗中の教師の相五. 作用行動が授業評価に及ほす影響一相互作用行動 に対する介入実験授業の分析を通して一。 スポー ツ教育学研究 $17: 73-83$.
高瀬克義・内藤勇次 · 浅川潔司・古川雅文 (1986) 青年期の環境移行と適応過程（1）。日本教育心理 学会第 28 回総会発表論文集：556-557. 戸川行男（1956）適応と欲求．金子書房：東京. 梅野圭史・中島 誠・後藤幸広・辻野 昭 (1997) 小学校体育科に扔ける学習効果（態度得点）に及 ぼす教師行動の影響。スポーツ教育学研究 17： $15-27$.

梅野圭史・过野 昭（1982）体育科における学習形 態と児童の授業に対する態度との関倸一小学椄低 学年を中心として一. 体育学研究 27：1-15.

吉村 斉（1997）学校適応における部活動とその人 間関係のあり方一自己表現・主張の重要性一，教 育心理学研究 $45 ： 337-345$.

$\left(\begin{array}{l}\text { 平成 } 13 \text { 年 } 3 \text { 月 } 19 \text { 日受付 } \\ \text { 平成 } 14 \text { 年 } 9 \text { 月 } 7 \text { 日受理 }\end{array}\right)$ 